\title{
Analysis of dividend policy of listed company and its financial impacts
}

\author{
Xian Mei,Xing Wei \\ Chengdu Aeronautic Vocational And Technical College, Chengdu, \\ 610100, China
}

\begin{abstract}
Dividend policy-making is an important part of enterprise profit distribution, and moderate and reasonable dividend distribution policy is beneficial to the development of enterprise and improving the earnings level in the future, as well as enhancing shareholder confidence in the enterprise, making the enterprise develop and grow in a healthy environment.This paper mainly describes the kinds and choices of dividend policy, and analyzes and determines the reasonable dividend policy aiming at the basic information of Qingdao Beer co., LTD.

Keywords: Dividend policy of the listed company; Dividend payment forms; Dividend policy decision; Financial analysis
\end{abstract}

\section{Introduction}

Dividend refers to return on investment that shareholders get from the company's net profits. In the final, enterprise woulddistribute the net profit according to the management level, and distribution of enterprisenet profit has three goals: the first is to pay down debt, making up the loss; the second is to provide development fund to the enterprise; the third is to return for investors. The choice of dividend policy is that managers balance the enterprise development and repaying the investors with investment interests, so that it can be more conducive to realize the development goals for enterprise in the future.

\section{Type of dividend policy}

\subsection{Surplus dividend policy}

Surplus dividend policy is the dividend policy that enterprise distributes the net profit achieved in this year under the premise of meeting the enterprise investment project.This policy is to combine the dividend policy of enterprise and corporate investment, financing behavior and analyze, only when the projects need to invest have good growth opportunities and the expected rate of return is greater than the necessary return rate shareholders demand, it can be chosen.This policy delivers the information to shareholdersthatthe enterprise 
future development ability is strong, and the investment project is trustworthy.

\subsection{Fixed dividend policy}

Fixed dividend policy is the dividend policy thatenterprise annual allocatethe fixed per share dividend amount, and will not change by other factors influence.This policy not only can stabilize stock price of the company, conveying to the investorsthe information that enterprise future development ability is stable, but also conducive to purchases and expenses of expected future dividends of the enterprise, advantageous for the enterprise financial management.Although the dividend policy is stable, but the fixed dividend may make the enterprise increase financial pressure in the yearwhich the net profit falls in, reduce the cash flow of the enterprise, and deteriorate the enterprise financial situation.So this policy is applicable to enterprises at the stable development stage.

\subsection{Steadily increasing dividend policy}

Steadily increasing dividend policy is the policy thatdividend per share maintains stable growth trend for enterprise during a period of time. The dividend policygenerally requires the dividend growth rate should be less than corporate profit growth rate.Only in this way, enterprises have enough net profits to realize the sustainable growth of dividend.This policy applies to enterprises at the mature period, and it will convey to the investors the information that corporateperformance is in the steady growth, and reduce the risk of corporate business.

\subsection{Fixed dividend payout rate dividend policy}

The policy is the dividend payment policy that the enterprise keeps fixed dividend payment rate, and actually makes the dividend of enterprise changing due to the difference of net profit.This policy requires companies can achieve a good profit every year. Because the dividend changes due to the difference of annual net income, the condition of business will show through the distribution of dividend when it is not good, making investors lose confidences, thusshare price fallsand enterprise value reduces.

\subsection{Low normal dividend and extra dividend policy}

The dividend policy is the policy that the enterprise, in the premise of maintaining lower fixed dividend every year, according to operating profit of enterprises this year, addsto the appropriate extra dividend.The dividend policy has large flexibility, which not only makes up for the risk of financial stress in the fixed dividend policy and solvesthe problem that in the fixed dividend payment rate the dividend distribution policy is not stable.Thus it is welcomed by most enterprises. 


\section{Evaluation index of dividend policy}

\subsection{Dividend payout rate}

Dividend payout rate refers to the ratio of annual realized total amount of dividends of the enterprise to realized total amount of net profit. The index directly reflects how many net profits the enterprise can distribute to shareholders each year, so it is an important indicator judging the dividend policy and for investors to choose stocks.A higher rate of dividend payment means enterprises dispatch a lot of dividends every year.A corresponding indicator is retained earnings ratio, which is the ratio of total net profit the enterprise each year leavesto implemented total net profit every year.

\subsection{Dividend yield}

The index is the ratio of the dividend per share and the stock price of enterprise, which reflects the earnings that corporate per share can achieve, and is an important indicatorinvestors judge investment risk of enterprise.

\section{Ways and characteristics of dividend payments}

\subsection{Cash dividend}

Cash dividend is a dividend distribution way that the enterprise distributes net profit to the shareholders in the form of cash. Giving out cash dividend can reduce agency cost,meet the preference of investors with low-come and transfer information for the future development of enterprises.

\subsection{Stock dividend}

Stock dividend is a dividend distribution way that the enterprise distributes net profit to the shareholders in the form of stock. Giving out stock dividend has functions on tax avoidance, reducing the enterprise shares, diluting share of shareholders and meetingthe preference of investors with high -come earners, etc.

\section{Financial impact of different dividend policy}

The determination of dividend policy has rules to follow, and reasonable dividend policy is helpful to enhance the confidence of investors, and to improve the development level.This paper takes financial statements information of Qingdao beer co., LTD. in nearly five years as the foundation, and analyzes and studies the decision characteristics of dividend policy.

\subsection{Current dividend policy of the company}

Dataof table 1 took the relevant data of annual statementof Qingdao beer co., 
LTD.from 2007 to 2011, on this account to analysis the company's current dividend policy.Qingdao beer plans to invest and establishChengdu branch office, and needs cash 1.25 billion, so the enterprise surplus cash amount is 90 million in 2007, 100 million in 2008, 260 million in 2009, 60 million in 2010,520 million in 2011.So in the next five years enterprise surplus cash amountsums to 1.03 billion.

Table 1 Dividend information of Qingdao beer co., LTD.

\begin{tabular}{|c|c|c|c|c|c|c|c|}
\hline Project & $\begin{array}{l}\text { Initial } \\
\text { period }\end{array}$ & 2007 & 2008 & 2009 & 2010 & 2011 & $\begin{array}{l}\text { Summa } \\
\text { ry }\end{array}$ \\
\hline $\begin{array}{l}\text { Earnings } \\
\text { per share } \\
\text { (yuan) }\end{array}$ & 0.46 & 0.46 & 0.52 & 0.59 & 0.54 & 0.77 & \\
\hline $\begin{array}{c}\text { Dividend } \\
\text { payout rate } \\
(\%)\end{array}$ & 0.22 & 0.22 & 0.22 & 0.16 & 0.18 & 0.26 & \\
\hline $\begin{array}{l}\text { Average } \\
\text { numbers } \\
\text { of shares } \\
\text { (million) }\end{array}$ & $\begin{array}{l}13000 \\
0\end{array}$ & $\begin{array}{l}13000 \\
0\end{array}$ & $\begin{array}{l}13000 \\
0\end{array}$ & $\begin{array}{l}13000 \\
0\end{array}$ & $\begin{array}{l}13000 \\
0\end{array}$ & $\begin{array}{l}13000 \\
0\end{array}$ & \\
\hline $\begin{array}{l}\text { Profits } \\
\text { available } \\
\text { for } \\
\text { distributin } \\
\text { g to the } \\
\text { shareholde } \\
\text { rs } \\
\text { (million) }\end{array}$ & & 60000 & 68000 & 77000 & 70000 & $\begin{array}{l}10000 \\
0\end{array}$ & 375000 \\
\hline $\begin{array}{c}\text { Out-of-poc } \\
\text { ket cost } \\
\text { (million) }\end{array}$ & & 36000 & 38000 & 26000 & 34000 & 13000 & 147000 \\
\hline $\begin{array}{l}\text { Cash } \\
\text { available } \\
\text { for } \\
\text { investment } \\
\quad \text { (million) } \\
\end{array}$ & & 24000 & 30000 & 51000 & 36000 & 87000 & 228000 \\
\hline $\begin{array}{l}\text { Cash } \\
\text { require } \\
\text { ments } \\
\text { of } \\
\text { investm } \\
\text { ent } \\
\text { project } \\
\quad \text { (millio }\end{array}$ & & 15000 & 20000 & 25000 & 30000 & 35000 & 125000 \\
\hline
\end{tabular}




\begin{tabular}{|c|l|l|l|l|l|l|l|}
\hline $\mathrm{n})$ & & & & & & & \\
\hline $\begin{array}{l}\text { Residual } \\
\text { cash } \\
\text { (million) }\end{array}$ & 9000 & 10000 & 26000 & 6000 & 52000 & 103000 \\
\hline
\end{tabular}

\subsection{Dividend distribution optimization decision}

If adopting the surplus dividend policy, because under the residual dividend policy, the cash is all distributed after the enterprise extracts needed amount of money for investment from net profit, the enterprise's cash balance is zero.And then it will push out the dividend per share and dividend payment rate of the enterprise.

Table 4 Dividend distribution under the residual dividend policy

\begin{tabular}{|c|c|c|c|c|c|c|c|}
\hline Project & $\begin{array}{l}\text { Initial } \\
\text { period }\end{array}$ & 2007 & 2008 & 2009 & 2010 & 2011 & Summary \\
\hline $\begin{array}{c}\text { Dividend per } \\
\text { share } \\
\text { (yuan) }\end{array}$ & 0.069 & 0.069 & 0.077 & 0.2 & 0.046 & 0.4 & \\
\hline $\begin{array}{c}\text { Dividend } \\
\text { payout rate } \\
(\%)\end{array}$ & & 15 & 14.8 & 33.9 & 8.52 & 51.95 & \\
\hline $\begin{array}{c}\text { Residual } \\
\text { cash } \\
\text { (million) }\end{array}$ & & 9000 & 10000 & 26000 & 6000 & 52000 & 103000 \\
\hline $\begin{array}{l}\text { Dividend } \\
\text { payout } \\
\text { (million) }\end{array}$ & & 9000 & 10000 & 26000 & 6000 & 52000 & 103000 \\
\hline $\begin{array}{l}\text { Cash surplus } \\
\text { (million) }\end{array}$ & & 0 & 0 & 0 & 0 & 0 & 0 \\
\hline
\end{tabular}

As shown in table 2, when adopting the remaining balance, company cash dividend policy is 0 , which make the enterprise cash be fully used, but under the policy the enterprise dividend payment rate is unstable, and it may cause dissatisfaction with the investors, and shake investors' confidence.At the same time, in-stable dividend payment rates may also affect the stock price of the enterprise and the value of the enterprise. So this policy is not reasonable.

If adopting the fixed dividend policy, the table 1 shows that net profit of enterprise in late five yearsis 3.75 billion, and in the five years enterprise surplus cash amount is 1.03 billion, thus the enterprise surplus cash accounts for about $27 \%$ of net profit, thus determines enterprise's dividend payment rate is $30 \%$.

Table 3 Dividend distribution under the fixed dividend policy

\begin{tabular}{|c|l|l|l|l|l|l|l|}
\hline Project & $\begin{array}{l}\text { Initial } \\
\text { perio } \\
\text { d }\end{array}$ & 2007 & 2008 & 2009 & 2010 & 2011 & $\begin{array}{l}\text { Summar } \\
\mathrm{y}\end{array}$ \\
\hline Dividend & 0.138 & 0.138 & 0.138 & 0.138 & 0.138 & 0.138 & \\
\hline
\end{tabular}




\begin{tabular}{|c|c|c|c|c|c|c|c|}
\hline $\begin{array}{c}\text { per share } \\
\text { (yuan) }\end{array}$ & & & & & & & \\
\hline $\begin{array}{c}\text { Dividend } \\
\text { payout rate } \\
(\%)\end{array}$ & 30 & 30 & 26.54 & 23.39 & 25.56 & 17.92 & \\
\hline $\begin{array}{l}\text { Residual } \\
\text { cash } \\
\text { (million } \\
\text { ) }\end{array}$ & & 9000 & $\begin{array}{l}1000 \\
0\end{array}$ & $\begin{array}{l}2600 \\
0\end{array}$ & 6000 & $\begin{array}{l}5200 \\
0\end{array}$ & 103000 \\
\hline $\begin{array}{c}\text { Dividend } \\
\text { payout } \\
\text { (million } \\
\text { ) }\end{array}$ & & $\begin{array}{l}1794 \\
0\end{array}$ & $\begin{array}{l}1794 \\
0\end{array}$ & $\begin{array}{l}1794 \\
0\end{array}$ & 17940 & $\begin{array}{l}1794 \\
0\end{array}$ & 89700 \\
\hline $\begin{array}{c}\text { Cash } \\
\text { surplus } \\
\text { (million) }\end{array}$ & & -8940 & -7940 & 8060 & $\begin{array}{l}-1194 \\
0\end{array}$ & $\begin{array}{l}3406 \\
0\end{array}$ & 13300 \\
\hline
\end{tabular}

As shown in table 3, when adopting the fixed dividend policy, the enterprise dividend maintains 0.138 , which is not only beneficial to maintain the stability of the stock price and is helpful for enterprises to predict the future annual demand for money.At the same time, corporate cash balances in five years amounts to 133 million, by contrast, the enterprise surplus cash amount is more, which shows that enterprises can not make good use of the cash, causing the lack of investment.

If adopting fixed dividend payout rate policy, from table 1 that the dividend payment rate is $30 \%$, under the fixed dividend payout rate policy, the dividend payout rate of enterprise is equal.

Table 4 Dividend distribution under the fixed dividend payout rate policy

\begin{tabular}{|c|l|l|l|l|l|l|l|}
\hline Project & $\begin{array}{l}\text { Initial } \\
\text { perio } \\
\mathrm{d}\end{array}$ & 2007 & 2008 & 2009 & $\begin{array}{l}201 \\
0\end{array}$ & 2011 & Summary \\
\hline $\begin{array}{c}\text { Dividend } \\
\text { per share } \\
\text { (yuan) }\end{array}$ & 0.138 & 0.138 & 0.156 & 0.177 & $\begin{array}{l}0.1 \\
62\end{array}$ & 0.231 & \\
\hline $\begin{array}{c}\text { Dividend } \\
\text { payout rate } \\
\text { (\%) }\end{array}$ & 30 & 30 & 30 & 30 & 30 & 30 & \\
\hline $\begin{array}{c}\text { Residual } \\
\text { cash } \\
\text { (million } \\
\text { ) }\end{array}$ & 9000 & 10000 & $\begin{array}{l}2600 \\
0\end{array}$ & $\begin{array}{l}600 \\
0\end{array}$ & $\begin{array}{l}5200 \\
0\end{array}$ & 103000 \\
\hline $\begin{array}{c}\text { Dividend } \\
\text { payout }\end{array}$ & 1794 & 20280 & $\begin{array}{l}2301 \\
0\end{array}$ & $\begin{array}{l}210 \\
60\end{array}$ & $\begin{array}{l}3003 \\
0\end{array}$ & 112320 \\
\hline
\end{tabular}




\begin{tabular}{|c|l|l|l|l|l|l|l|}
\hline $\begin{array}{c}\text { (million } \\
\text { ) }\end{array}$ & & & & & & \\
\hline $\begin{array}{c}\text { Cash } \\
\text { surplus } \\
\text { (million) }\end{array}$ & & -8940 & $\begin{array}{l}-1028 \\
0\end{array}$ & 2990 & $\begin{array}{l}-15 \\
060\end{array}$ & $\begin{array}{l}2197 \\
0\end{array}$ & -9320 \\
\hline
\end{tabular}

As shown in table 4, the enterprise cash shortage is 93.2 million for five years.So companies need to raise money from outside to make up the shortage of funds.In order to make up the shortage of money, it needs to pay a certain amount of financing costs and taxes, which will occupythe additional funds.

\section{Conclusion}

Based on the above analysis,it can be seen that under the three kinds of given dividend policy, the fixed dividend policy and the fixed dividend payment rate policies are optional.If under the fixed dividend policy, the investment income of surplus cash is greater than the financing cost and tax under the fixed dividend payment rate policy, the fixed dividend policy.On the contrary, the fixed dividend payment rate policy should be chosen.

\section{Reference}

1. [1] Yin Yanting. A brief analysis of dividend distribution policy of listed companies in our country [J].Sci-Tech Information Development \& Economy, 2011, (19).

2. [2] ChenLihua. Study on dividend policy of listed companies in our country [J]. Journal of Contemporary Economy, 2009, (13).

3. [3] Zheng Tian. Theory of Vanke company dividend policy and its enlightenment [J].Journal of Management Information in China, 2010, (22).

4. [4] Ding Yunfeng. A brief talkof dividend distribution policy of the joint-stock company[J].Journal of Western Finance andAccounting, 2009, (8).

5. [5] Zhang Wenjia. Research on dividend decision problem of listed company in our country [M]. Anhui: China University of Science and Technology, 2004, (5) 